\title{
COMPARATIVE EFFICACY OF CLOVE OIL AND 2-PHENOXY ETHANOL ON SERUM BIOCHEMICAL CHANGES AND HISTOLOGICAL STUDIES IN CHANNAPUNCTATUS
}

\author{
"G. Chella durai ${ }^{1}$, J. Mohan raj $^{1}$, S. Subbu lakshmi ${ }^{2}$ \\ ${ }^{1}$ Department of Advanced Zoology \& Biotechnology, Kamaraj College, Thoothukudi, Tamilnadu, India \\ ${ }^{2}$ Department of Microbiology, Kamaraj College, Thoothukudi, Tamilnadu, India \\ *Corresponding author:G.chelladurai,chellam.zoo@gmail.com.9629484026
}

\begin{abstract}
The aim of the present study was to investigate thecomparison of effect of clove oil and 2-phenoxy ethanol for Channapunctatus and using values of serum biochemical profile and histological tissue studies ,to assess the effects of fish exposure to that anaesthetic:A total of 60 C.punctatus of $60.23 \pm 5.02 \mathrm{~g}$ were divided in to five groups (12 fish per each): $1^{\text {st }}$ treatment as control (no anaesthetic), $2^{\text {nd }} 0.2 \mathrm{ml} / 1$ 2-phenoxy ethanol, $3^{\text {rd }} 0.3 \mathrm{ml} / 12$-phenoxy ethanol, $4^{\text {th }} 30 \mathrm{mg} / 1$ clove oil and $5^{\text {th }} 40 \mathrm{mg} / 1$ clove oil.Biochemical blood profile of C.puntatus were taken $15 \mathrm{~min}$ and $24 \mathrm{hrs}$. After Anaesthesia induction ,the factors used to evaluate the serum biochemical profile included the glucose (GLU), total protein (TP), albumin (ALB),total globulin (GLOP), alkaline phosphatase (ALP), serum Glutamic oxaloacetic Transaminase (SGOT), serum glutamic pyruvic transaminase (SGPT), histological tissue examination of tissue like gills ,ten minutes exposure to 2-phenoxy ethanol and clove oilcaused an increase in concentration of glucose and alkaline phosphatase $15 \mathrm{~min}$ after Anaesthesiainduction.Histological examination showed.Capillary ectasia of gill filaments immediately after clove oil and 2-phenoxy ethanol,showed swelling of primary and secondary lamella .Twenty -four hours after anaesthesia ,no ectasia was observed .No histopathological changes were demonstrated in gills:Our result showed that The 2-phenoxy ethanol at $0.20 \mathrm{ml} / 1$ and clove oil at $30 \mathrm{mg} / 1$ concentration may be used as an efficient and safe anaesthetic for Channapunctatus.
\end{abstract}

Key words: Clove oil, 2-Phenoxy ethanol,Channapunctaus,Serum biochemical profile, histological examination of tissues.

\section{INTRODUCTION}

Anaesthetics are one of the groups of pharmaceutical preparation. They have been used extensive and intensive fish culture to reduce the effects of stress on fish and to lower mortality after handling and transporting large stock of fish.Generalanaesthetics have been applied for many years in fisheries.The anaesthetics are used with increasing frequency on aquaculture, mainly to reduce the stress and to prevent mechanical damage to fish during handling..The most widely used anaesthetics include MS222,(Mundey and nilson,1997;Ross and ross,1999). 2 Phenoxy ethanol, quinaldine ,quinaldinesulphate and clove oil, modern fish anaethetics must meet a number of general requirement,e.g. They must be highly soluble in water, take effect quickly be safe for both fish and human's have broad safety margins, allow anadlibitum intensification of anaesthesia with possibility of spontaneous recovery and they must leave no residues. Clove oil is dark brown liquid,adistillate of flowers stalks and leaves of the clove tree. Eugenia aromatic (soto and Burhanuddin, 1995).At the present clove oil is used for short -term immobilizationof the fish before artificial spewing. The recommended concentration for anaesthetic purposes is $30 \mathrm{mg} / 1$ of water both (Svobboda and kolarova, 1999; Hamackova et al., 2001).

The first use of 2-phenoxy ethanol to anaesthetize salmonids was reported in 1963 from Canada (Sehdevet al., 1963;Boel 1964).2-Phenoxy (Ethylene Glycol mono phenoxylether) is used for short term immobilization of fish before artificial spawning and generally recommended concentration is $0.20 \mathrm{ml} / 1$ of water bath for big breeding fishes, the recommended concentration is $0.30 \mathrm{ml} / 1$ of water bath .At the recommended concentration anaesthesia is induced within 5 to $10 \mathrm{~min}$.when transferredto clean water ,fish will recover with in 10min (Svoboda and Kolarova 1999;Hamackova et al.,2001).The efficacy is conditioned by environmental (Temperature , $\mathrm{p}^{\mathrm{H}}$, and biological factors (Size, weight lipid content and fish species ,(Bukraet al .,1997; Ross and Ross,1999).The anaesthesia subsides and physiological reflexes are restored within 10 minutes after the fish are transferred to clean water (Svobodova,J.Kolarova and S.Narratilet al.,2007. The present study was to evaluate the effects of clove oil and 2-phenoxy ethanol on serum biochemical parameters and Histological studies in Channapunctatus .

\section{MATERIALS METHODS}

Healthy Channapunctatus were transported from korampallam fish tank. The fish were acclimated in the laboratory for 10 days. The water use in the experiment had the following mean values for water characteristics :temperature $24 \pm 0.1, \mathrm{P}^{\mathrm{H}} 7.4 \pm 0.1$, and the dissolve oxygen (DO) were oxygen was observed above $7 \mathrm{mgi}^{-1} \cdot 1^{\text {st }}$ group serve as control (no anaesthesia), $2^{\text {nd }} 0.2 \mathrm{ml} / 12$-phenoxy ethanol, $3^{\text {rd }}$ $0.3 \mathrm{ml} / 12$-phenoxy ethanol, $4^{\text {th }} 30 \mathrm{mg} / 1$ clove oil and $5^{\text {th }}$ $40 \mathrm{mg} / 1$ clove oil .The clove oil (90\% eugenol) was first dissolved in $95 \%$ ethanol at the ration of 1:2 (Clove oil :ethanol) and then diluted by shaking with water. The solution was added to the experimental tank $30 \mathrm{~min}$ before the introduction of fishes. The induction time carried out in two 30 liter aquaria for $10 \mathrm{~min}$ the fishes were exposed to anaesthesia .

Changes in the physiological status of anaesthetized fish were assessed in four consecutive stages (Thienpointand Niemeggeers 1965):

1. Acceleration and subsequent declaration of breathing movements, a partial loss of reactivity to external stimuli:

2. Loss of balance breathing movement'svery slow, fish still reactive to strong stimuli.

3. Total loss of reactivity, fish are lying at the bank bottom and do not respond to handling. 
4. Complete cessation of opercula movements of fish die if left in the bath for too long.

\section{Biochemical examination of blood plasma}

The biochemical indices in plasma included; glucose (GLU),total protein(TP), albumin(ALB) ,total globulin(GLOB), alkaline phosphatase (ALP),serum glutamic oxaloacetic transaminase (SGOT), serum glutamic pyruvic transaminase (SGPT),Blood plasma was obtained by centrifuge Blood samples in a cooling centrifuge (4 ${ }^{0} \mathrm{C}, 1000 \times \mathrm{g}$ ).For biochemical analysis of blood plasma,VETTEST 8008 analyzer in vivak laboratories from Tamilnadu.India.The result are presented as mean \pm SE.multiple comparison were performed by ANOVA and followed by the Tukey honestly significant different (HSD) test in all analyses ,the level of significance was set to $(\mathrm{p}<0.05)$.

\section{Histiological Examination of tissue}

For histological examination of tissue, channapunctatus of $60.23 \pm 5.02 \mathrm{~g}$ (mean $\pm \mathrm{SD}$ ), bodyweight and $32 \pm 2.01 \mathrm{~mm}$ body length were used. After blood sampling samples of gills were taken for histological examination .The samples taken were immediately fixed in $10 \%$ formaldehyde drained and embedded in paraffin, section were made of the paraffin blocks and stained with haematoxylin -eosin.

\section{RESULT}

Ten min exposure to 2-phenoxy ethanol at a concentration of 0.20 and $0.30 \mathrm{ml} / 1$ cause increase in the concentration of glucose and ALP (alanine phosphatase $15 \mathrm{~min}$ after anaesthesia induction $(\mathrm{P}<0.05)$. Their values returned back to normal with in $24 \mathrm{hrs}$.also $10 \mathrm{~min}$ exposure to clove oil at concentration of 30 and $40 \mathrm{mg}$ an increase in the concentration of glucose $.15 \mathrm{~min}$ after anaesthesia induction $(\mathrm{p}<0.05)$.Also concentration of $40 \mathrm{mg} / 1$ clove oil caused an increase in alkaline phosphatase. (ALP). $15 \mathrm{~min}$ after anesthesia induction $(p<0.05)$. Their values returned back to normal within 24 hours, there was no significant changes in other parameter's (TP,ALB,GLOB,SGOT,SGPT).

\section{Histological examination of tissues}

All specimens of Channapunctatus. Showed capillary ectasia(Fig:1A) of gill filaments 15 mints after clove oil .and, twenty four ,hours after anaesthesia ,no histopathological changes were demonstrated on other tissue of liver. Section of 2 phenoxy ethanol treated with gills showed swelling of primary and secondary lamellae (FIG.2A).after twenty four hours anaesthesia no histopathologicalchanges.

Table1: Effects of clove oil and 2-phenoxy ethanol on serum biochemical parameters , 15min after anaesthesia induction (Mean \pm SE)

\begin{tabular}{|c|c|c|c|c|c|c|c|}
\hline Group & GLU & $\mathrm{TP}$ & Alb & Glob & ALP & SGOT & SGPT \\
\hline Control & $85.72 \pm 2.01^{\mathrm{a}}$ & $3.17 \pm 0.02^{\mathrm{a}}$ & $3.21 \pm 0.05^{\mathrm{a}}$ & $1.62 \pm 0.02^{\mathrm{c}}$ & $40.17 \pm 3.13^{c}$ & $79.01 \pm 3.29^{\mathrm{a}}$ & $26.31 \pm 1.61^{b}$ \\
\hline Group 1 & $91.73 \pm 3.17^{\mathrm{a}}$ & $3.28 \pm 0.01^{b}$ & $3.75 \pm 0.02^{b}$ & $1.79 \pm 0.05^{\mathrm{a}}$ & $119.2 \pm 02.71^{\mathrm{a}}$ & $78.32 \pm 2.32^{\mathrm{a}}$ & $26.78 \pm 1.05^{\mathrm{a}}$ \\
\hline Group 2 & $121.08 \pm 4.12^{\mathrm{c}}$ & $2.66 \pm 0.02^{\mathrm{a}}$ & $4.32 \pm 0.33^{\mathrm{a}}$ & $2.98 \pm 0.15^{\mathrm{a}}$ & $120.10 \pm 3.12^{\mathrm{a}, \mathrm{b}}$ & $54.34 \pm 1.38$ & $14.81 \pm 2.05^{\mathrm{a}}$ \\
\hline Group 3 & $101.12 \pm 3.18^{\mathrm{a}}$ & $2.75 \pm 0.01^{b}$ & $5.14 \pm 0.03^{b}$ & $3.31 \pm 0.17$ & $121.33 \pm 1.55^{\mathrm{c}}$ & $61.53 \pm 2.75^{\mathrm{a}, \mathrm{b}}$ & $19.73 \pm 1.78^{\mathrm{a}}$ \\
\hline Group 4 & $105.63 .19^{\mathrm{a}}$ & $2.53 \pm 0.01^{\mathrm{a}}$ & $4.21 \pm 0.04^{b}$ & $2.76 \pm 0.17^{\mathrm{a}}$ & $23.57 \pm 3.31^{b}$ & $60.12 \pm 1.32^{\mathrm{a}}$ & $18.31 \pm 1.29^{\mathrm{qa}}$ \\
\hline
\end{tabular}

Table2: Effects of clove oil and 2-phenoxy ethanolon serum biochemical a parameters, 24 hours after anaesthesia induction (Mean $\pm \mathrm{SE})$

\begin{tabular}{|l|l|l|l|l|l|l|l|}
\hline Group & GLU & TP & Alb & Glob & ALP & SGOT & SGPT \\
\hline Control & $91.42 \pm 1.02$ & $2.10 \pm 0.20$ & $3.81 \pm 0.06$ & $2.01 \pm 0.01$ & $40.19 \pm 2.13$ & $78.40 \pm 2.14$ & $27.31 \pm 1.20$ \\
\hline Group 1 & $92.41 \pm 2.13$ & $3.14 \pm 0.21$ & $3.65 \pm 0.01$ & $1.91 \pm 0.06$ & $115 \pm 2.14$ & $79.11 \pm 1.89$ & $27.18 \pm 1.04$ \\
\hline Group 2 & $90.31 \pm 3.14$ & $2.77 \pm 0.20$ & $4.33 \pm 0.44$ & $3.14 \pm 0.16$ & $121.01 \pm 2.14$ & $55.14 \pm 1.22$ & $14.11 \pm 2.01$ \\
\hline Group 3 & $102.21 \pm 2.14$ & $2.86 \pm 0.02$ & $6.12 \pm 0.04$ & $3.44 \pm 0.50$ & $120.03 \pm 1.81$ & $60.51 \pm 1.77$ & $19.71 \pm .60$ \\
\hline Group 4 & $103.06 \pm 3.14$ & $2.65 \pm 0.01$ & $4.01 \pm 0.01$ & $1.89 \pm 2.10$ & $24.31 \pm 3.11$ & $59.11 \pm 1.30$ & $19.03 \pm 1.09$ \\
\hline
\end{tabular}

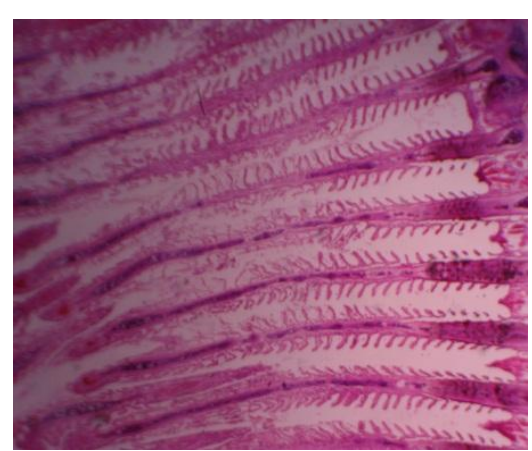

Figure 1A: Control clove oil

\section{DISCUSSION}

Anesthetics are necessary for many hatchery procedures in aquaculture. Because species may differ widely in their response to the same anaesthetics screening of dosage of different anaesthetics is often necessary.(Hekla's et al., 1986) ㄷ 2011, JDDT. All Rights Reserved

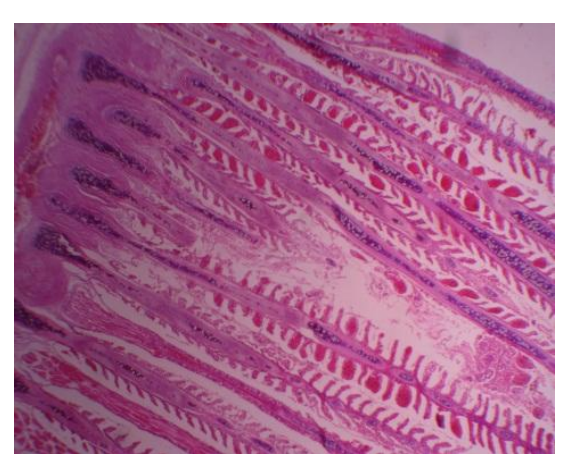

Figure 1B: 15mnts after anesthesia with clove oil

recommended 25-100ppm clove oil as effectiveananesthesia for the C.punctatus. To evaluate biochemical profile of blood and histological changes in tissues of C.punctatus2-phenoxy ethanol 0.20 and $0.03 \mathrm{ml} / 1$ clove oil concentration 30 and $40 \mathrm{mg} / 1$ were used in the present study. Values are 
determined in the present study suggest that internal organs and tissuse of C.punctatus by used presented anaesthetics.In our experiment with C.punctatus, asignificantly increase $(\mathrm{p}<0.05)$ in blood plasma glucose $15 \mathrm{~min}$ after the 2-phenoxy ethanol and clove oil anaesthesia was observed. Increase blood plasma glucose level after anaesthesia indicates that the procedure caused some stress in C.punctatus.These finding are accord with results of Holloway et al., (2004) and veliseket al., (2005).The ALP decrease in blood plasma indicates that the anaesthetics does not damage paranchymatus tissues in C.punctauts. Anaesthesiawith 2phenoxy ethanol at the concentration of 4000ppm and 2 min exposure time had no effect on tryptophan, 5-hydroxy tryptamine, dopamine or norepinephrine, levels in the brain of rain bow trout (Sloleyet al., 1986). Clove oil has been used as an anaesthetic in density for a long time the anaesthetic properties and dosages of clove oil have been tested on different fishes (Griffiths,S.P.,2000 and Tayllor,P.W. and S.D.Robertset al.,1999).In addition, some physiological reaction of fish exposed to clove oil have also been reported (Keene,.J.L..andS.D.Rebertset al., 1998).clove oil may be also

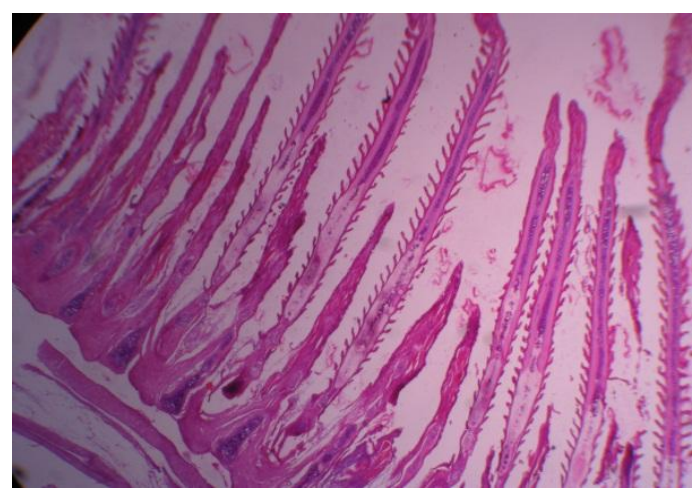

Fig 2A: 15mints after anaesthesia with 2 phenoxy ethanol be good for use in aquaculture and during the live transportation of fishes the disadvantage of clove oil is its relatively low therapeutic index.i.e ratio between the therapeutic and the toxic concentrations. Thegenerally reported optimum ratio is 1:4 or higher (Svobodova and VYKusoya, 1991).Amajordrawback of 2-phenoxy ethanol is that it requires rather high anaesthetic doses in fishes. The range of effective anesthetic doses of 2-phenoxy ethanol in most fish species are from about 0.20 to $0.60 \mathrm{ml} / 1$ (Guo, FC.,L.H.Teo and Chen.,1995)ortunoet al reported an increase in glucose and cortisol values in Sparusaurata anesthetized with 2-phenoxy ethanol.When 2-phenoxy ethanolissued, labor safety regulation should be strictly observed because the anaesthetic is toxic and harmful to human. Furthermore, it should be noted that, as 2-phenoxy ethanol is noted approved for use in food fish, we do not advocate its use in any fish unless MRL values (EEC regulation 2377190)are set and proper licensing is acquired .In conclusion our results showed that 2-phenoxy ethanol $0.20 \mathrm{ml} / 1$ vand clove oil at $30 \mathrm{mg} / 1$ concentration may be used as an efficient and safe anesthetic for C.punctatus.

\section{ACKNOWLEDGMENTS}

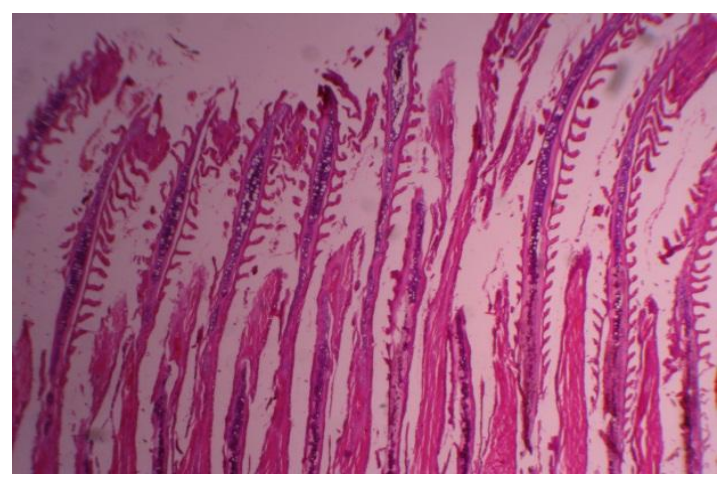

Fig 2B: Control 2 phenoxy ethanol

The authors are thankful to Director, Kama raj college, Tuticorin for giving suggestion and encouragement during the study period.

\section{REFERENCE}

1. Ross, L.G and B.Ross, 1999, Anaesthetic and sedative Techniqes for aquatic animals. $2^{\text {nd }}$ ed. Black well science Ltd., Oxford, PP: 159.

2. Holloway AC, Keene JL, NoakesD.G.Moccia RD. Effects of clove oil and MS 222 on blood hormone profile in rainbow trout oncorhynchusmykiss, Walbaum. Aquac Res: 2004, 35 : 1025 - 1030.

3. Velisek J. svobodova X, piackova, V, Groch, Nepejchalova L, Effects of clove oil anaesthesia on common carp (cyprinuscarpio) vet med czech 2005, $50: 269-275$.

4. Keene. J.K, Noakes, D.L.G., Moccia, R.D. and Soto, C.D. The efficacy clove oil as an anaesthetic for rainbow trout, oncorhynchusmykiss) Aquaculture Research, 1998, 29:89-101.

5. Hamackova J., Sevdova J.M., Pjanova S.V., Lepicova A. The effect 2-Phenoxy enthanol, clove oil and propiscinanaesthetics on perch (PercaFluviatilis) in relation to water temperature. ZechJournal of animal science, 2001, 46,469-473.

6. Taylor P.W., Roberts S.D. clove oil : An alternative anaesthetic for aquaculture. North American Journal of Aquaculture, 1999, 161, 150 - 155.related to water temperature vetererinarniMedicina, 49, 467472 .

7. Hikasa Y., Takasek., Ogasawara T., Ogasawara S. Anaesthesia and recovery with tricanemethanesulphonate, eugenol and thiopental sodium in the carp (cyprinuscarpio) Japanese, Journal of veterinary science, 1986, 48, 341-351.

8. Svobodova,Z.,J.Kolarova,S.Novratil,T.Vesely.,P.Chloupek and J.Tesarcik,2007.Disease of freshwater and aquarium fish. Info.Praha.(In Czech).
9. TheinpointD.,Niemogeers.C.J.E. R746 a new potent anesthetic for aquaculture:North American cyu, 1965, 4150-155.

10. SvobodaZ., Vykusova B.(1991):Dignostics, prevention and therapy of fish disease and intoxication .Manual for international training course on fresh water fish disease and intoxication.Research institute of fish culture and hydrobiology, vodnany 270pp.

11. Griffiths,S.P. The use of clove oil as an anaesthetic and methods for sampling intertidal rock pool fiches.j.fishBio, 2000, 57:1453-1464.

12. Guo,F.C.,L.H.teo and T.W.chen, Effects of anaesthetics on the water parameters in a stimulated transport.experiment of platy Fish,Xiphophorusamculates (*Gunther).Aqua.Res., 1995, 26;265-27.

13. Svoboda M, Kolarova J. A survey of anaethetics used in the fish farming. Health protection of fish.Proceeding of papers.Researchinstitue of fish culture and Hydrobiology vodnary, 1999, P.P.49-72.

14. Burka, J.F., Hammell, K.L., Horsberg, T.E., Johnson, G.R., Rainnie, D.J., Speare, D.J. drugs in Salmonid aquaculture - a review. j.vetPharmacol. ther, 1997, 20, $333-349$.

15. Heo, G.J., Shin,G. Efficacy of benzocaine as an anaesthetic for Crucian Carp [CarassiusCarassius].Vet.Anaesth.Analg.2010, 37.132135 .

16. Otero - Ferrer, F., Molina, L., Socorro, J., Herrer, R., FernaLndex Palacios, H.,Jzquierdo. M.S. Live prey first feeding regimes for short - snouted seahorse Hippocampus Hippocampus (Linnaeus, 1758) Juveniles. Aquac.Res. 2010, 1-12. 